\title{
CHARACTERIZATION OF BAMBOO TUTUL CHARCOAL PARTICLE PRODUCED BY HIGH ENERGY BALL MILLING SHAKER TYPE
}

\author{
Supriyono, B. Susilo \\ Dept. of Mechanical Engineering, Faculty of Engineering, Universitas Muhammadiyah Sura- \\ karta, Indonesia
}

Email: supriyono@ums.ac.id

\begin{abstract}
The objective of this study is to characterize bamboo tutul charcoal particles produced by High Energy Ball Milling (HBEM) shaker type. The HEBM process was conducted in the stainless steel vials for 2 million cycles at 900 motor RPM. The ball milling diameter was 1/4 inch made from steel. Therefore, perhaps the final particle size will be determined by empty space of the vial for the movement of the balls. In this study, the empty space is varied for 1/2, 1/3, 1/4, and 1/5 of vial volume. Particle Size Analyzer (PSA) is used to have the particle sizes and SEM-EDX is used to have surface morphology of the particle. The average final particle sizes are $547.8 \mathrm{~nm}, 522.9 \mathrm{~nm}, 422.7 \mathrm{~nm}$, and $739.4 \mathrm{~nm}$ for $1 / 2,1 / 3,1 / 4$, and 1/5 empty space of vial respectively. The surface morphologies of the particles are determined by fracture mechanism as they can be seen on the SEM results. Based on the results, it can be said that there is no correlation between the particle size and the empty space of the vial. As long as there is space for movement of the milling balls, the collision occurs and the reduction of the particle also happens.
\end{abstract}

Keywords: bamboo, charcoal, high energy ball milling, particle.

\section{INTRODUCTION}

Charcoal is a natural material obtained from pyrolysis process of wood. It has been used as fuel for many years. The biggest content of charcoal is carbon. Carbon is one of the materials that has advantages in terms of physical and chemical characteristic[1]. The development of nanomaterial is very fast including carbon nano. In nanotechnology, a particle is defined as a small object that behaves as a whole to its nature and its transport.

Bamboo has been known by the community for long time. Bamboo has many application in day life. It is versatile and can be easily retrieved in our environment. Bamboo has benefit not only from the side of conservation but also provides financial profit. Bamboo is very potential commodities. It is due to many application of bamboo, consequently a lot of waste material produced from theits application. The waste material can be transformed into charcoal as carbon source.

Until recently, the production of carbon nanoparticles from various carbon sources such as glucose, sugar, siklodekstrin, fructose, cellulose, sucrose, starch, amylopectin, organic molecules, and waste biomass has already undertaken by many researchers [2]. For example, Z. Shuo et al. [5] and the stabilized samples were then carbonized at $600 \mathrm{u} 00 \mathrm{~b} 0 \mathrm{C}$ for $1 \mathrm{~h}$ under N2atmosphere. In the process, stabilization treatment was the main step. The mechanism of stabilization was investigated by thermogravimetric analysis, X-ray diffraction, $\mathrm{X}$-ray photoelectron spectroscopy, and differential scanning calorimetry, and the morphology of the carbon spheres was characterized by scanning electron microscopy (SEM, has done 
research on the production process of spherical carbon derived potato flour with the method of carbonization. N. Mohan, et.,al. [6], has done research about synthesis of carbon nano sphere obtained from the thermal decomposition of petrol, diesel, paraffin, and lubricants. J. Rao. et. al. [7], successfully modified micrometer-sized carbide silicon powder into carbide silicone particle nanometer powder by ball milling process using 30 hours milling time parameter, 10 gram and 50 gram steel ball weight ratio.

Some other researchers have worked on nanoparticle obtained from bamboo. For example Anuj Kumar, et.al.[3], studied the effect of bamboo fiber density on mechanical strength and water absorption. L Zou, et. al. [1], examined the nanoparticle structure characteristic and the mechanical properties of bamboo fiber. J.Q. Krause, et. al.[4], scrutinized effect of bamboo micro structure on tensile and compressive strength..

Supriyono, et. al.[8], has wroked on the effect of the ball size on the product characteristics of shaker HBEM to produce nano particle from bamboo charcoal. F. G. Salihati,et.,al, [9] did a research on carbon manufacture from bamboo ori and bamboo petung. The carbon can be produced by heating the bamboos for 1 hour. Jiaguan Zhan, et.al, [10]moreover the biggest mean contact force and the highest energy utilization ratio of balls could be acquired when the speed ratio is 1.5. The mean contact force increases with the proportion increasing of the large balls, which means ball size distribution has some effect on the crushing and grinding process. And according to the experimental results for comparative analysis, the specific rates of breakage Si increases with the proportion rise of large balls in ball size distribution, meanwhile Si can be determined by the mean contact force(Fmcf examined effects of milling speed, size of steel balls, and the time of milling on the final particle size of the initial $20 \mu \mathrm{m}$ pellet. The results shows that ball size has certain effect on the particle size, the larger the ball diameter the larger the average particle size. S.Giat,et. al, [11] conducted a research on Co-Cr-Mo combination with mechanical mixing method in wet milling condition using High Energy Milling for 50 hours milling time. The weight ratio of the powder and the ball is 15 gram powder and 75 gram [11].

This research carried out a characterization of bamboo tutul charcoal nanoparticles resulted from high energy ball milling (HEBM) shaker type the same as the work done by Supriyono et al [8]. However, since the milling process is conducted in a vial, the empty space of the vial for the ball movement will determine the final size of the particles.

\section{EXPERIMENT}

\section{Powder Preparation}

Charcoal was produced by pyrolysis process of waste material of bamboo tutul (Bambusa maculata). To have the powder the charcoal is manually milled. To have a uniform size of powder, the powder from the manual milling is filtered to 200 mesh size.

\section{Experiment}

The milling process was conducted in vials as it can be seen in Figure 1. The vials are made from stainless steel cylinder with diameter of 2 inches and length of $120 \mathrm{~mm}$. At the once milling process, 4 vials are used. The milling ball has diameter of $1 / 4$ inch. The powder and the ball are put into the vials according to Table 1 . The vials are placed on the shaker machine as it can be seen in Figure 2. The shaking movement is obtained from transformation rotation into translation by connecting rod. This movement has shaking effect to the vials. 


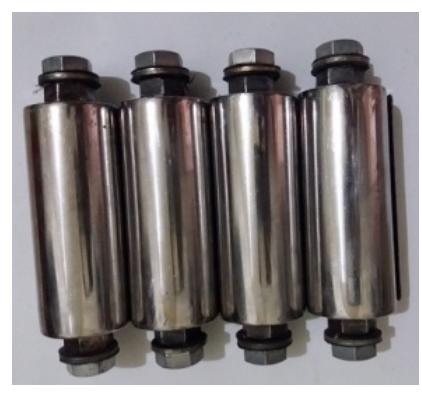

Figure 1. Vials to conduct milling process

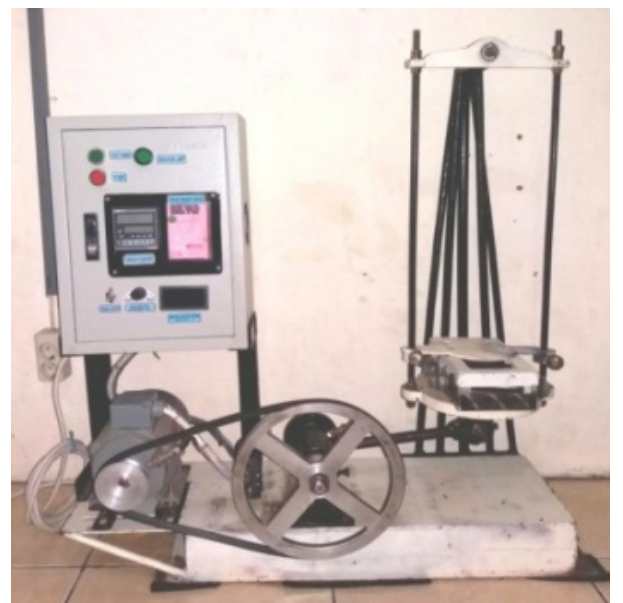

Figure 2. Shaking machine

The milling process was conducted for 2 million cycles at $900 \mathrm{rpm}$ of driving motor.

Table 1. Content of vials

\begin{tabular}{|c|c|c|c|c|c|}
\hline \multirow{2}{*}{$\begin{array}{l}\text { No. } \\
\text { Vial }\end{array}$} & \multirow{2}{*}{$\begin{array}{l}\text { Empty } \\
\text { volume }\end{array}$} & \multicolumn{2}{|c|}{ Dose } & \multirow{2}{*}{$\begin{array}{l}\text { Total } \\
\text { Ball }\end{array}$} & \multirow{2}{*}{$\begin{array}{c}\text { Weight } \\
\text { Ball } \\
\text { (gr) }\end{array}$} \\
\hline & & $\begin{array}{l}\text { charcoal } \\
\text { powder }\end{array}$ & Ball & & \\
\hline 1 & $1 / 2$ & $1 / 4$ & $1 / 4$ & 260 & 279,19 \\
\hline 2 & $1 / 3$ & $1 / 3$ & $1 / 3$ & 347 & 360,60 \\
\hline 3 & $1 / 4$ & $3 / 8$ & $3 / 8$ & 390 & 405,29 \\
\hline 4 & $1 / 5$ & $2 / 5$ & $2 / 5$ & 416 & 432,31 \\
\hline
\end{tabular}

\section{RESULTS AND DISCUSSION}

Particle size analyzer (PSA) results are shown in Table 2 and Figure 3.

Table 2. PSA Results

\begin{tabular}{cc}
\hline $\begin{array}{c}\text { Volume Empty on } \\
\text { Tubes }\end{array}$ & Particle Size Results (nm) \\
\hline $1 / 2$ & 547.8 \\
$1 / 3$ & 522.9 \\
$1 / 4$ & 422.7 \\
$1 / 5$ & 739.4 \\
\hline
\end{tabular}




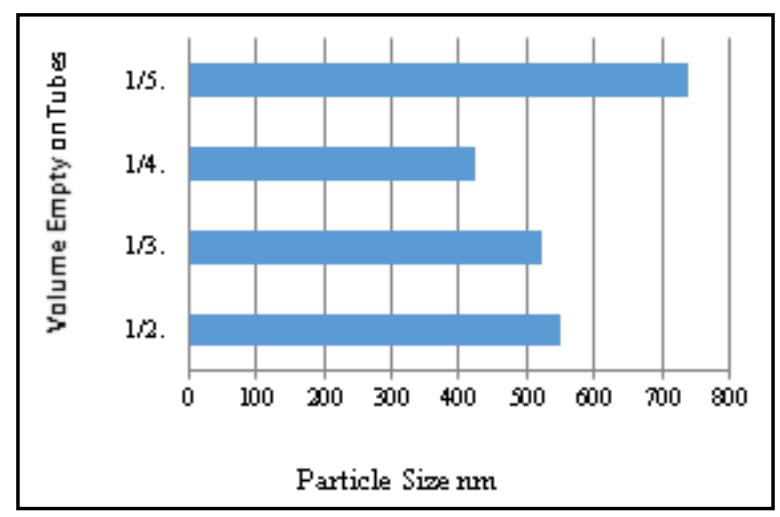

Figure 3. Graphic of average particle size

The PSA results show that the final sizes of the particle are in between $422.7 \mathrm{~nm}$ and $739.4 \mathrm{~nm}$. The smallest one is produced by the vial with $1 / 4$ empty space and the biggest one is produced by the vial with $1 / 5$ empty space. The particle size are not in standard of nanoparticle since according to A. Kumar, et. al ., nanoparticle is particle in the size of 1 to $100 \mathrm{~nm}$ [3]. The PSA results are in line with SEM results shown in Figure 4. It can be seen from the SEM results that the distribution on the particle sizes for each empty space are not homogen. There are particles with the size of more than 1 micron, on the other hand many particles are less than 1 micron.

The SEM results show that the surface morphology is determine by fracture mechanism. According to the work by P. Kuziora et., al.[12]such the vial volume, the diameter and quantity of milling balls and the powder mass. In this experiment, different batches of magnesium hydride powder were milled using varying ball size, powder mass, and other parameters and a constant BPR. The hydrogen desorption properties (i.e., differential scanning calorimeter, the surface morphology of the particle is influenced by some variables, such as the ball milling size of the sphere and the grinding speed. Whereas the grinding speed is affected by the motor speed and the empty space for the movement of the ball.

As it has been mentioned in the above paragraph that the distributions of the particle size of each empty space are not homogeny. Kim et al.[13] said that HEBM has steady state time which is a limit time where the increase time of milling has no effect on the particle size. It means that the size distribution is homogeny. The conclusion of this research is supported by $\mathrm{J}$. Eckert and I. Borner [14]
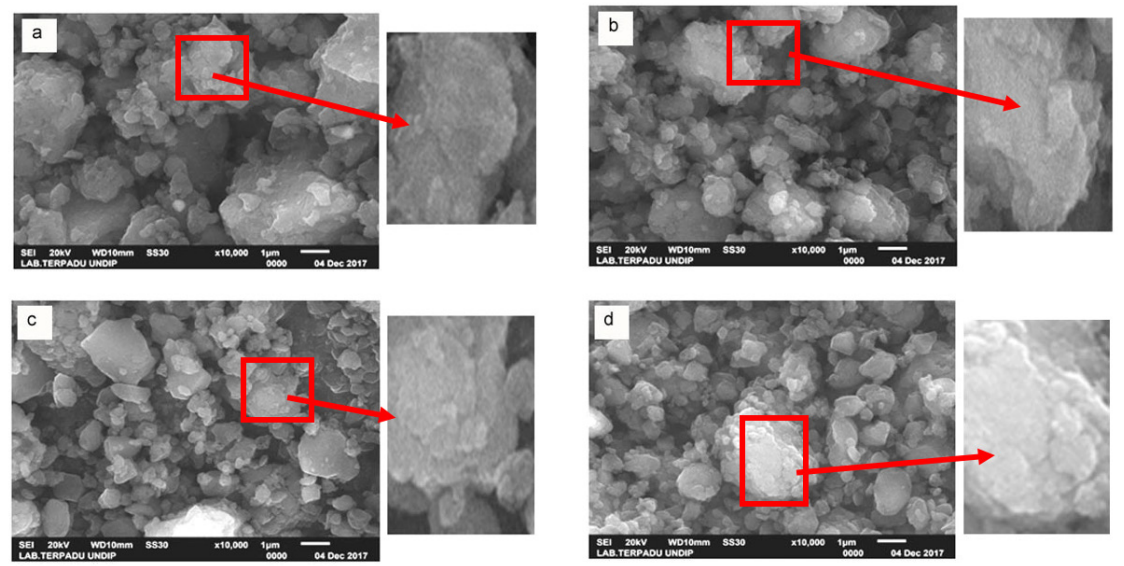

Figure 4. Results of SEM, comparison (a) $1 / 2$ empty space of vial, (b) 1/3 empty space of vial, (c) $1 / 4$ empty space of vial and (d) 1/5 empty space of vial. 
From EDX, it can be seen the composition of bamboo charcoal, and the result is shown in Table 2 as follows:

Table 3. EDX Results

\begin{tabular}{lcccc}
\hline \multirow{2}{*}{$\begin{array}{c}\text { Chemical } \\
\text { elements }\end{array}$} & \multicolumn{4}{c}{ Composition (\%) } \\
\cline { 2 - 5 } & $\mathbf{1 / 2} \mathbf{\mathbf { 1 } / \mathbf { 2 }}$ & $\mathbf{1 / 3} \mathbf{: 2 / 3}$ & $\mathbf{1 / 4}: \mathbf{3 / 4}$ & $\mathbf{1 / 5} \mathbf{\mathbf { 4 } / \mathbf { 5 }}$ \\
\hline $\mathrm{C}$ & 95,6 & 93,03 & 97,33 & 96,22 \\
$\mathrm{SiO}_{2}$ & 0,36 & 0,61 & 0,25 & 0,77 \\
$\mathrm{~K}_{2} \mathrm{O}$ & 0,71 & 0,64 & 0,66 & 1,39 \\
$\mathrm{CuO}$ & 0,68 & 0,62 & 0,63 & 0,68 \\
$\mathrm{ZnO}$ & 0,26 & 0,32 & 0,38 & 0 \\
$\mathrm{ZrO}_{2}$ & 0,84 & 0,72 & 0,74 & 0,78 \\
$\mathrm{P}_{2} \mathrm{O} 5$ & 0,37 & 1,19 & 0 & 0,16 \\
$\mathrm{~K}_{2} \mathrm{O}$ & 0,49 & 0,47 & 0,66 & 0,51 \\
\hline
\end{tabular}

In EDX testing it can be seen the most dominant composition is element $\mathrm{C}$ (Carbon) with the percentage above $93.3 \%$ this is because bamboo charcoal is also active carbon. There are also other elements contained in the bamboo charcoal. In accordance with EDX result shown in Table 3, it is possible to separate the carbon element with other chemical elements caused by the occurrence of the agglomeration region. The most dominant chemical element is carbon, so bamboo charcoal is a potential source of nanoparticle carbon.

\section{CONCLUSIONS}

Based on results of the work, it can be concluded that: The empty space variation of vial does not have any effect on the final particle size. The more empty space, the more freely the ball movement as a grinder, and this variable influence the grinding speed which affect the surface morphology of the particle. By having 2 million cycles in this work, the steady state condition is not reached yet.

\section{REFERENCES}

[1] L. Zou, H. Jin, W.-Y. Lu, and X. Li, "Nanoscale structural and mechanical characterization of the cell wall of bamboo fibers," Mater. Sci. Eng. C, vol. 29, no. 4, pp. 1375-1379, 2009.

[2] D. B.Effendi, N.H. Rosyid, A. Bayu, and D. Nandiyanto, "Review : Sintesis Nanoselulosa," J. Untirta, vol. 5, no. 2, pp. 61-74, 2015.

[3] A. Kumar et al., "Engineered bamboo scrimber: Influence of density on the mechanical and water absorption properties," Constr. Build. Mater., vol. 127, pp. 815-827, 2016.

[4] J. Q. Krause, F. de Andrade Silva, K. Ghavami, O. da F. M. Gomes, and R. D. T. Filho, "On the influence of Dendrocalamus giganteus bamboo microstructure on its mechanical behavior," Constr. Build. Mater., vol. 127, pp. 199-209, 2016.

[5] S. Zhao, C. Y. Wang, M. M. Chen, Z. Q. Shi, and N. Liu, "Preparation of carbon spheres from potato starch and its stabilization mechanism," Xinxing Tan Cailiao/New Carbon Mater, vol. 25, no. 6, pp. 438-443, 2010.

[6] A. N. Mohan and B. Manoj, "Synthesis and characterization of carbon nanospheres from hydrocarbon soot," Int. J. Electrochem. Sci., vol. 7, no. 10, pp. 9537-9549, 2012. 
[7] J. Rao, G. Catherin, in Murthy, D. Rao, and B. Raju, "Production of nano structured silicon carbide by high energy ball milling," Int. J. Eng. Sci. Technol., vol. 3, no. 4, pp. 82-88, 2011.

[8] Supriyono, Ngafwan, W Joharwan, "The effect of the ball size on the product characteristics of shaker HEM to produce nano particle from bamboo charcoal", IOP Conf. Ser.: Mater. Sci. Eng. 403 $012090,2018$.

[9] F. G. Salihati and H. Ardhyananta, "Studi Pembuatan Karbon Hitam dari Bambu Ori (Bambusa arundinacea) dan Bambu Petung (Dendrocalamus asper)," Tek. Pomits, vol. 1, no. 2, pp. 1-6, 2013.

[10] J. Zhang, Y. Bai, H. Dong, Q. Wu, and X. Ye, "Influence of ball size distribution on grinding effect in horizontal planetary ball mill," Adv. Powder Technol., vol. 25, no. 3, pp. 983-990, 2014.

[11] S. Giat and W. Ari, "Pembentukan Nanopartikel Paduan CoCrMo Dengan Metoda Pemanduan Mekanik," Pus. Teknol. Bahan Ind. Nukl. - BATAN, 2012.

[12] P. Kuziora, M. Wyszyńska, M. Polanski, and J. Bystrzycki, "Why the ball to powder ratio (BPR) is insufficient for describing the mechanical ball milling process," Int. J. Hydrogen Energy, vol. 39, no. 18, pp. 9883-9887, 2014.

[13] Y. Do Kim, J. Y. Chung, J. Kim, and H. Jeon, "Formation of nanocrystalline Fe-Co powders produced by mechanical alloying," Mater. Sci. Eng. A, vol. 291, no. 1, pp. 1721,2000 .

[14] J. Eckert and I. Börner, "Nanostructure formation and properties of ball-milled NiAl intermetallic compound," Mater. Sci. Eng. A, vol. 239-240, pp. 619-624, 1997. 